\title{
POLITIK HUKUM PENGUATAN DESENTRALISASI FISKAL DALAM MENINGKATKAN KESEJAHTERAAN MASYARAKAT DAERAH
}

\author{
Agus Darmawan \\ Kementerian Keuangan Republik Indonesia \\ email : agus.gic@gmail.com
}

\begin{abstract}
The study aims to find a legal political model the Indonesian government in the implementation of fiscal decentralization that is oriented towards improving the welfare of people in the area. Using normative approach can be concluded that the system updates the state financial management with the adoption of several laws in the management of state finances, among others, by arranging the principles of best (best practice) management of state finances, budgeting system and the structure of the budget, control range (span of control) financial administration, oversight and accountability mechanisms of state financial management, which is also applied in the area of financial management. However, developments in the field of state financial arrangements turned out to show a tendency towards recentralisation power system, at least in the areas of fiscal, necessitating the re-strengthening fiscal decentralization of financial management in order to achieve the welfare of all Indonesian people.
\end{abstract}

Keywords: Politics Law, Fiscal Decentralization and Local Government

abstrak

Penelitian bertujuan untuk menemukan model politik hukum pemerintah Indonesia dalam pelaksanaan desentralisasi fiskal yang berorientasi pada peningkatan kesejahteraan rakyat di daerah. Menggunakan pendekatan normatif dapat disimpulkan bahwa pembaruan sistem pengelolaan keuangan negara dengan ditetapkannya beberapa undang-undang dalam pengelolaan keuangan negara, antara lain dengan mengatur prinsip-prinsip terbaik (best practice) pengelolaan keuangan negara, sistem penganggaran dan struktur APBN, rentang kendali (span of control) administrasi keuangan, mekanisme pengawasan dan pertanggungjawaban pengelolaan keuangan negara, yang juga diterapkan dalam pengelolaan keuangan daerah. Namun demikian, perkembangan pengaturan di bidang keuangan negara ternyata memperlihatkan kecenderungan ke arah resentralisasi sistem kekuasaan, sekurang-kurangnya di bidang fiskal, sehingga diperlukan upaya penguatan kembali desentralisasi fiskal pengelolaan keuangan daerah dalam rangka mencapai kesejahteraan seluruh rakyat Indonesia. 
Kata kunci : Politik Hukum, Desentralisasi Fiskal dan Pemerintah Daerah.

\section{A. Pendahuluan}

Politik hukum diartikan sebagai kebijakan dasar penyelenggara negara dalam bidang hukum yang akan, sedang, dan telah berlaku, yang bersumber dari nilai-nilai yang berlaku di masyarakat untuk mencapai tujuan negara yang dicita-citakan. Tujuan dari politik hukum nasional adalah sebagai alat (tool) atau sarana dan langkah yang dapat digunakan oleh pemerintah untuk menciptakan suatu sistem hukum nasional yang dikehendaki dan dengan sistem hukum nasional itu akan diwujudkan cita-cita bangsa Indonesia yang lebih besar. ${ }^{1}$

Pada tataran empiris, politik hukum dipergunakan Moh. Mahfud MD sebagai pendekatan dalam memahami relasi antara hukum dan politik. ${ }^{2}$ Moh. Mahfud MD mendefinisikan Politik Hukum sebagai arah kebijakan hukum (legal policy) yang dibuat secara resmi oleh negara tentang hukum yang akan diberlakukan atau tidak akan diberlakukan untuk mencapai tujuan negara. $^{3}$ Hukum ditempatkan sebagai alat untuk mencapai tujuan negara sehingga pembuatan hukum baru atau pencabutan hukum lama oleh negara harus dijadikan langkah untuk mencapai tujuan negara. ${ }^{4}$ Supremasi hukum diartikan dengan meletakan hukum sebagai sentral pengarah dan pedoman dalam upaya pencapaian tujuan negara melalui politik hukum nasional bukan sebagai instrumen untuk mendukung kemauan eksekutif atau pemerintah yang sedang berkuasa. ${ }^{5}$

Salah satu tujuan Negara yang dimuat dalam Pembukaan UUD 1945 adalah tercapainya kesejahteraan masyarakat Indonesia. Untuk itu, pondasi perekonomian Indonesia perlu diperkuat dengan salah satunya melalui pengaturan pengelolaan keuangan negara yang baik dalam rangka mencapai tujuan tersebut.

Pengertian Keuangan negara menurut Geodhart adalah keseluruhan undang-undang yang ditetapkan secara periodik yang memberikan kekuasaan pemerintah untuk melaksanakan pengeluaran mengenai periode tertentu dan menunjukan alat pembiayaan yang diperlukan untuk menutup pengeluaran tersebut. Sedangkan pengertian Anggaran Belanja Pemerintah menurut Jhon F.Due adalah suatu pernyataan mengenai pengeluaran atau

\footnotetext{
${ }^{1}$ Imam Syaukani dan A.Ahsin Thohari, Dasar-Dasar Politik Hukum, (Jakarta: Rajawali Pers, 2013), hlm. 58.

${ }^{2}$ Moh. Mahfud MD. Perdebatan Hukum Tata Negara Pascaamandemen Konstitusi. (Jakarta: PT Raja Grafindo Persada, 2010), hlm. 49.

${ }^{3}$ Ibid.

${ }^{4}$ Ibid.

${ }^{5}$ Ibid.
} 
belanja yang diusulkan dan penerimaan untuk masa mendatang bersama dengan data tentang pengeluaran dan penerimaan sebenarnya untuk periode yang telah lampau. ${ }^{6}$

Pasal 1.1 Undang-Undang Keuangan negara, pengertian Keuangan negara sebagai semua hak dan kewajiban Negara yang dapat dinilai dengan uang, serta segala sesuatu baik berupa uang maupun berupa barang yang dapat dijadikan kewajiban yang dapat dinilai milik Negara berhubungan dengan pelaksanaan hak dan kewajiban tersebut. Pendekatan yang dipergunakan untuk merumuskan definisi stipulatif keuangan negara dari sisi objek, subjek, proses, dan tujuan.

Dari sisi objek, Keuangan negara meliputi semua hak dan kewajiban yang dapat dinilai dengan uang, termasuk kebijakan dan kegiatan dalam bidang fiskal, moneter, dan pengelolaan kekayaan Negara yang dipisahkan, serta segala sesuatu baik berupa uang, maupun berupa barang yang dapat dijadikan milik negara berhubungan dengan pelaksanaan hak dan kewajiban tersebut.

Dari sisi subjek, Keuangan negara meliputi seluruh objek sebagaimana tersebut di atas yang dimiliki negara, dan/atau dikuasai oleh Pemerintah Pusat, Pemerintah daerah, Perusahaan negara/daerah, dan badan lain yang ada kaitannya dengan keuangan negara.

Dari sisi proses, Keuangan negara mencakup seluruh rangkaian kegiatan yang berkaitan dengan pengelolaan objek sebagaimana tersebut di atas mulai dari perumusan kebijakan dan pengambilan keputusan sampai dengan pertanggungjawaban.

Dari sisi tujuan, Keuangan negara meliputi seluruh kebijakan, kegiatan dan hubungan hukum yang berkaitan dengan pemilikan dan/atau penguasaan objek sebagaimana tersebut di atas dalam rangka penyelenggaraan pemerintah Negara.

Secara historis yuridis pengaturan Keuangan negara dimulai pada tahun 1864 pada saat ditetapkannya Indonesische Comptabiliteit Wet (ICW), yang berlaku pertama kali pada tanggal 1 Januari 1967. Riwayat ICW tersebut, terkait dengan perubahan paradigma Grandwet Nederland 1848, yang memberikan kewenangan perubahan lebih kuat kepada parlemen untuk melakukan fungsi kontrol keuangan negara.

Di Hindia Belanda, pada tahun 1917 Gubernur Jenderal memiliki kewenangan menetapkan sementara anggaran. Kemudian, setelah dibentuk Volksraad mulai dilakukan perintisan kearah fungsi kontrol parlemen, meskipun sampai dengan tahun 1925 kewenangan dalam hal financiele beleid masih berada di tangan Gubernur Jenderal Hindia Belanda.

\footnotetext{
${ }^{6}$ Handyaningrat, Soewarno, Administrasi Pemerintahan Dalam Pembangunan Nasional, (Jakarta: Haji Masagung, 1982), hlm. 172.
} 
Setelah Indonesia merdeka, ICW masih diberlakukan melalui pasal II Aturan Peralihan UUD 1945, sampai kemudian diubah menjadi UndangUndang Perbendaharaan Indonesia (UPI) melalui UU Nomor 6 Tahun 1968. Dikeluarkannya UU Nomor 17 Tahun 2003 tentang Keuangan Negara, merupakan wujud kebijakan untuk melakukan perubahan paradigma hukum keuangan negara agar dapat membangun sistem pengelolaan keuangan negara yang efektif, efisien taat asas, dan sesuai dengan prinsip-prinsip good governance. Setelah dikeluarkan UU Nomor 17 Tahun 2003, disusul dikeluarkan UU Nomor 1 Tahun 2004 tentang Perbendaharaan Negara, UU Nomor 15 Tahun 2004 tentang Pemeriksaan Pengelolaan dan Pertanggungjawaban Keuangan Negara (yang kemudian dikenal sebagai "Paket Undang-Undang di Bidang Keuangan Negara") sebagai instrumen untuk melakukan birocratic reform dalam administrasi keuangan negara. Hal itu diperlukan untuk melakukan pembaharuan visi pengelolaan keuangan negara, yang semula didasarkan atas UPI yang masih mengandung paradigma "kolonial".

Politik hukum keuangan negara berupa pembaharuan sistem keuangan negara memiliki beberapa implikasi penting dalam pengelolaan keuangan negara. Pertama, redefinisi visi pengelolaan keuangan negara untuk mewujudkan tujuan bernegara. Dalam rangka penerapan visi tersebut pengelolaan keuangan negara didasarkan atas asas-asas klasik dan asas-asas baru. Asas-asas klasik meliputi: asas tahunan, asas universalitas, asas kesatuan, dan asas spesialitas. Sedangkan asas-asas baru sebagai pencerminan penerapan kaidah-kaidah yang baik (best practice) pengelolaan keuangan negara terdiri dari: akuntabilitas berorientasi pada hasil, profesionalitas, proporsionalitas, keterbukaan dalam pengelolaan keuangan negara, dan pemeriksaan keuangan negara oleh badan pemeriksa yang bebas dan mandiri.

Kedua, rekonstruksi rentang kendali (span of control) organisasi dalam pengelolaan keuangan negara memperjelas sistem pendelegasian wewenang dalam pengelolaan keuangan negara. Menteri Keuangan sebagai pembantu Presiden dalam bidang keuangan adalah sebagai Chief Financial Officer (CFO) Pemerintah RI. Sedangkan setiap Menteri/pimpinan lembaga adalah sebagai Chief Operational Officer (COO) untuk suatu bidang tertentu pemerintahan. Berdasarkan prinsip pembagian kewenangan itu, Kementerian Keuangan berwenang dan bertanggung jawab atas pengelolaan aset dan kewajiban Negara secara nasional. Sementara itu, Kementerian/lembaga berwenang dan bertanggung jawab atas penyelenggaraan pemerintahan sesuai dengan tugas dan fungsi masing-masing.

Ketiga, pemisahan secara tegas pemegang kekauasaan administratif dengan pemegang kewenangan kebendaharaan akan meningkatkan akuntabilitas dan menjamin terselenggaranya saling uji (check and balances) 
dalam proses pelaksanaan anggaran. Menguatnya wibawa parlemen dalam melaksanakan fungsi pengawasan politik terhadap pemerintah, akan memperketat sistem pengawasan dalam kerangka pembagian kekuasaan Negara secara horizontal, yang diharapkan mampu meminimalisasikan kalau belum mampu mengeliminasikan penyalahgunaan wewenang dalam pengelolaan keuangan negara. Terlebih UU Keuangan negara telah secara tegas menyebutkan anggaran sebagai "instrumen akuntabilitas, manajemen dan kebijakan ekonomi”. Sebagai konsekuensinya, pasal 32 UU Kekayaan Negara mengharuskan penyusunan Standar Akuntansi Pemerintah (SAP) melalui Peraturan Pemerintah oleh suatu Komite Standar. Hal ini dapat menjadi entry point guna membangun good governance dalam tata kelola keuangan negara.

Keempat, sebagai wujud komitmen untuk melaksanakan pengelolaan keuangan negara secara efektif, efisien, dan cermat, maka defisit anggaran perlu dikendalikan dalam setiap penyusunan anggaran Negara. Implikasinya pasal 4 ayat (1) PP Nomor 23 Tahun 2003 mengatur bahwa jumlah kumulatif defisit APBN dan APBD tidak melebihi 3\% dari PDB tahun bersangkutan. Regulasi ini diharapkan dapat menjaga stabilitas ekonomi makro melalui kinerja fiskal yang sehat dan berkesinambungan.

Kelima, diintroduksikan penerapan secara penuh anggaran berbasis kinerja di sektor publik yang diikuti dengan perubahan klasifikasi anggaran agar sesuai dengan klasifikasi yang digunakan secara internasional. Sistem klasifikasi anggaran yang selama ini dilakukan dalam bentuk anggaran rutin dan anggaran pembangunan yang semula dilakukan untuk menekankan arti pentingnya pembangunan, justru selama ini telah menyebabkan terjadinya duplikasi, penumpukan, dan bahkan penyimpangan anggaran. Perubahan sistem klasifikasi anggaran diarahkan menjadi sistem perencanaan fiskal seperti di negara maju, yang terdiri dari sistem penyusunan anggaran tahunan yang dilaksanakan sesuai dengan Kerangka Pengeluaran Jangka Menengah (Medium term expenditure framework).

Perkembangan pengaturan di bidang keuangan negara, di satu sisi berimplikasi positif sebagaimana diuraikan di atas. Namun demikian, di sisi lain perkembangan pengaturan di bidang keuangan negara ternyata memperlihatkan kecenderungan ke arah resentralisasi sistem kekuasaan, sekurang-kurangnya di bidang fiskal. Ditinjau dari sudut pembiayaan pemerintah (governance financing), karena instrumen fiskal merupakan instrumen vital dalam penyelenggaraan kekuasaan, resentralisasi di bidang fiskal dapat mereduksi makna otonomi bagi daerah.

Beberapa indikator yang memperlihatkan kecenderungan perluasan kewenangan pusat di satu sisi dan penyempitan kewenangan daerah di bidang fiskal di sisi lain dapat dilihat berikut ini. Pertama, UU Nomor 17 Tahun 2003 tentang Keuangan Negara yang mendesain sistem pengelolaan 
keuangan negara secara sentralistik. Keleluasaan daerah dalam penyusunan APBD secara ketat harus mengacu pada desain pusat mengenai pokok-pokok kebijakan fiskal dan kerangka ekonomi makro bagi rancangan anggaran yang disusun oleh pusat. Hal ini lebih terlihat secara lebih jelas pada pasal 8 PP Nomor 20 tahun 2004 tentang Rencana Kerja Pemerintah yang menyatakan bahwa hasil-hasil program pembangunan harus secara sinergis mendukung pencapaian sasaran pembangunan nasional yang ditetapkan dalam RPJM Nasional. Melalui UU Nomor 17 Tahun 2003 tersebut Kementerian Keuangan memperoleh perluasan kekuasaan sebagai otorisator sekaligus ordonator khusus keuangan negara. Dari segi kekuasaan pemerintahan secara umum, kekuasaan pemerintah pusat sendiri sudah sangat luas dalam hal proses alokasi dana perimbangan kepada pemerintah daerah. Dana perimbangan tersebut menurut pasal 10 UU Nomor 33 Tahun 2004 tentang Perimbangan keuangan antara Pemerintah Pusat dan Pemerintah Daerah terdiri atas: dana bagi hasil, dana alokasi umum, dan dana alokasi khusus.

Pelimpahan kewenangan terhadap sumber-sumber penerimaan negara kepada pemerintah daerah sebenarnya sangat diperlukan untuk mengefektifkan pelaksanaan tugas-tugas rutin, pelayanan publik dan peningkatan investasi yang produktif (capital investment) bagi daerah. Hal tersebut harus dipertimbangkan oleh Pemerintah dalam rangka mendukung pelaksanaan desentralisasi UU Sistem Perencanaan Pembangunan Nasional yang terlihat lebih cenderung memberikan penekanan pada model perencanaan terpusat dan terkesan developmentalis dapat menjadi kebijakan yang bersifat paradoks dengan arah desentralisasi kekuasaan.

Kedua, semakin diperluasnya kewenangan Kementerian Dalam Negeri dalam melakukan kontrol fiskal terhadap Pemerintah Daerah. Pasal 175 ayat (1) UU Nomor 32 Tahun 2004 tentang Pemerintahan Daerah (Pemda) memberikan kewenangan atributif kepada Mendagri untuk melakukan pengendalian defisit anggaran setiap daerah. Selanjutnya, pasal 175 ayat (2) mewajibkan pemerintah daerah melaporkan posisi surplus/defisit APBD kepada Mendagri dan Menteri Keuangan setiap semester dalam tahun anggaran berjalan. Apabila pemerintah daerah tidak melaksanakan kewajiban sebagaimana disebutkan dalam pasal 175 ayat (2) tersebut, pemerintah dapat menjatuhkan sanksi berupa penundaan penyaluran dana perimbangan. Hal tersebut memperlihatkan semakin diperkuatnya kewenangan Pusat dalam melakukan pengendalian kebijakan fiskal daerah. Pada masa berlakunya UU Nomor 22 Tahun 1999 sebelumnya, kewenangan pengendalian kebijakan fiskal daerah semacam itu memang tidak diatur secara tegas. Cukup banyak daerah yang karena kurang cermat dalam mendesain kebijakan keuangan daerah mengalami defisit keuangan, bahkan ada beberapa daerah yang sampai menunggak melakukan 
pembayaran kepada para pegawainya karena tidak tersedianya komponen anggaran rutin untuk membayar gaji PNS. Pengalaman kasus semacam itu yang tampaknya melatarbelakangi keinginan pemerintah pusat diberikan akses untuk melakukan kontrol terhadap kebijakan fiskal bagi daerah. Namun, penekanan yang berlebihan untuk selalu ingin secara ketat mengontrol kebijakan fiskal bagi daerah dapat mematikan kreatifitas dan menutup ruang inovasi bagi daerah dalam bidang pengelolaan keuangan daerah.

Di sisi lain, diperkuatnya kewenangan Gubernur sebagai aparat dekonsentrasi untuk mengevaluasi rancangan Perda tentang APBD dan rancangan Peraturan Bupati/Walikota tentang Penjabaran APBD dalam pasal 186 UU Pemda memperlihatkan perluasan kewenangan dekonsentrasi dalam sistem penyelenggaraan pemerintahan daerah. Instrumen pengawasan Gubernur tersebut tersebut berupa kewenangan pembatalan Perda dan Peraturan Bupati/Walikota tersebut, sekaligus menyatakan berlakunya pagu APBD tahun sebelumnya. Dalam konteks kewenangan pembatalan tersebut Gubernur sebenarnya merupakan kepanjangan tangan dari Mendagri. Sebenarnya, hal tersebut telah mengubah kedudukan Gubernur yang seharusnya menjadi intermediate governance menjadi subordinat governance, yang akan lebih berorientasi secara vertikal ke atas. Hal tersebut tentu saja bisa mempersempit ruang otonomi bagi daerah sebagai wilayah administratif pusat.

Ketiga, reduksi peranan DPRD yang oleh UU Nomor 32 Tahun 2004 diklasifikasikan sebagai unsur penyelenggara pemerintah daerah daripada sebagai parlemen daerah. Hal itu berpengaruh terhadap semakin menyempitnya kewenangan DPRD dalam menjalankan fungsi legislasi, anggaran dan pengawasan. Seharusnya kedudukan DPRD adalah sebagai parlemen lokal yang mampu melaksanakan secara efektif fungsi-fungsi pokoknya tersebut. Subordinasi kedudukan dan fungsi DPRD di bawah struktur kekuasaan eksekutif menyebabkan melemahnya kapasitas DPRD dalam mengartikulasikan kepentingan rakyat di daerah. Lemahnya kekuasaan legislatif daerah dapat mereduksi makna otonomi daerah, karena DPRD memiliki fungsi vital untuk menjamin terakomodasinya kepentingan rakyat daerah dalam berbagai produksi regulasi lokal.

Berdasarkan uraian-uraian tersebut, jurnal ini akan meninjau kembali politik hukum keuangan negara berkenaan dengan perlunya penguatan "desentralisasi fiskal" setelah melihat indikasi dan fakta-fakta adanya gejala resentralisasi di bidang fiskal yang mereduksi makna otonomi bagi daerah pasca ditetapkannya paket undang-undang di bidang keuangan negara. 


\section{B. Pembahasan}

\section{Transformasi Hukum Keuangan Negara}

Transformasi sistem demokrasi turut mengubah paradigma pemerintahan yang semula berkarakter birokratik, sentralisme, dan top down oriented menjadi karakter partisipatif, desentralistik dengan penguatan kapasitas lokal (local capacity) dan bottom up oriented berbasis kerakyatan. Hal tersebut dinilai berimplikasi terhadap dilakukannya penataan kelembagaan (institutional arrangement), reformasi aparat birokrasi (civil servant reform) dan pembaruan sistem pengelolaan keuangan negara (the new financial management reform).

Pembaruan sistem pengelolaan keuangan negara dilakukan antara lain dengan mengatur prinsip-prinsip terbaik (best practice) pengelolaan keuangan negara, sistem penganggaran dan struktur APBN, rentang kendali (span of control) administrasi keuangan, mekanisme pengawasan, dan pertanggungjawaban pengelolaan keuangan negara.

Diperkenalkannya asas akuntabilitas berorientasi pada hasil (result oriented accountability) atau akuntabilitas kinerja (performance accountability) dalam asas-asas umum, perubahan klasifikasi anggaran dan mekanisme penetapan Rencana Kerja dan Anggaran (RKA) pada pasal-pasal UU Keuangan negara, dinilai menunjukan adanya pembongkaran terhadap bias paradigma hukum keuangan negara. Beberapa Pembaruan sistem pengelolaan keuangan negara tersebut dapat dilihat dalam tabel 1.

Tabel 1

Perubahan Pengaturan Hukum Keuangan Negara dalam Undangundang Keuangan Negara 2003

\begin{tabular}{|l|c|l|}
\hline $\begin{array}{c}\text { Pokok- } \\
\text { pokok } \\
\text { Perubahan }\end{array}$ & Pasal & \multicolumn{1}{|c|}{ Diskripsi } \\
\hline Prinsip & 3 & $\begin{array}{l}\text { Tertib, taat pada Tertib, taat pada peraturan } \\
\text { Per-UU-an, efisien, ekonomis, efektif, } \\
\text { transparan, dan bertanggung jawab }\end{array}$ \\
\hline Otoritas & 6 & $\begin{array}{l}\text { Presiden memegang kendali pengelolaan } \\
\text { keuangan negara sebagai the chief of } \\
\text { executive }\end{array}$ \\
\hline $\begin{array}{l}\text { Kebijakan } \\
\text { fiskal }\end{array}$ & 8,13 & $\begin{array}{l}\text { Ada desain kebijakan fiskal dan kerangka } \\
\text { ekonomi makro sebagai acuan penyusunan } \\
\text { APBN }\end{array}$ \\
\hline $\begin{array}{l}\text { Struktur } \\
\text { APBN }\end{array}$ & 12 & $\begin{array}{l}\text { Berorientasi program, berbasis kinerja, } \\
\text { surplus/defisit disebutkan secara jelas dalam } \\
\text { APBN, I Account. }\end{array}$ \\
\hline
\end{tabular}




\begin{tabular}{|l|c|l|}
\hline $\begin{array}{l}\text { Sistem } \\
\text { penganggaran }\end{array}$ & $11-15$ & $\begin{array}{l}\text { Pokok kebijakan fiskal, Rencana Kerja dan } \\
\text { Anggaran berbasis prestasi kerja }\end{array}$ \\
\hline $\begin{array}{l}\text { Pertanggung } \\
\text { jawaban }\end{array}$ & $30-33$ & $\begin{array}{l}\text { Prinsip akuntabilitas dan penegasan kontrol } \\
\text { parlemen }\end{array}$ \\
\hline
\end{tabular}

Pada masa Hindia Belanda, difungsikannya institusi Algemene Rekenkamer (yang menjadi cikal bakal institusi BPK pada masa berikutnya) sebagai badan peradilan bagi bendaharawan berdasarkan Pasal 59 ICW 1925 Stb.1924 No. 448, cenderung mempermudah pembelokan pertanggungjawaban keuangan negara, yang sebenarnya mengandung dimensi tindak pidana korupsi, menjadi sekedar permasalahan administratif. Pasal 34 UU tentang Keuangan Negara dengan tegas mengklasifikasikan penyimpangan kebijakan dan kegiatan anggaran negara dalam APBN/D sebagai bentuk tindak pidana. Melalui UU tindak pidana korupsi kasus-kasus penyimpangan kebijakan dan anggaran yang bernuansa pidana dapat ditingkatkan kualifikasinya sebagai suatu extra ordinary crime.

Penyusunan RAPBN juga lebih mengarah pada prinsip transparansi, demokratis dan measurable, karena diawali dengan skenario penyusunan pokok-pokok kebijakan fiskal dan kerangka ekonomi makro, yang diajukan oleh Pemerintah dan dibahas bersama-sama dengan DPR. DPR memiliki fungsi korektif dan memiliki hak veto untuk menolak usulan kebijakan dari Pemerintah.

Menteri/pimpinan lembaga selaku pengguna anggaran menyusun Rencana Kerja dan Anggaran berbasis kinerja. Orientasi akuntabilitas kinerja (performance accountability) pada hasil mengharuskan dikembangkannya indikator kinerja (performance indicators) berdasarkan pengumpulan data kinerja (performance data collection system). Hal itu, akan menstimulasi kinerja kelembagaan pemerintah dengan keharusan dilakukannya penguatan kapasitas (capacity building), guna memenuhi target kinerja yang diharuskan untuk dicapai dalam pengukuran kinerja pemanfaatan anggaran. Pergeseran model anggaran line-item menjadi anggaran berbasis akuntabilitas kinerja menjadi suatu keharusan. Implikasi berikutnya adalah peningkatan kualitas kinerja pemerintahan yang berorientasi pada pelayanan publik.

Model anggaran line-item yang dilaksanakan UPI pada masa lalu menyebabkan terjadinya: (1) Dikotomi anggaran rutin dan pembangunan yang tidak jelas; (2) Basis alokasi yang tidak jelas. Perubahan model anggaran menjadi I-Account akan memperjelas basis anggaran, surplus/defisit anggaran, dan sumber-sumber pembiayaan anggaran.

Penerimaan pajak mengalami peningkatan dari Rp. 211 triliun pada tahun 2002 menjadi Rp. 241,6 triliun pada tahun 2003. Angka tersebut melampaui pengeluaran rutin sebesar Rp. 190,1 triliun. Meskipun banyak faktor yang mempengaruhi hal tersebut, namun salah satunya adalah 
transformasi hukum keuangan negara yang mampu mendorong penghematan pengeluaran negara dan sekaligus melakukan efisiensi pengelolaan keuangan negara.

Transformasi paradigma hukum keuangan negara teramat penting bagi suatu negara, seperti yang dilakukan melalui UU Nomor 17 Tahun 2003 tentang Keuangan negara. Sehubungan dengan fungsi anggaran Negara, dikatakan oleh Hughes" bahwa "There are two main function for the government budget in overall sense, economic functions and financial functions. Economic functions concern how the government, through the budget, influences the entire economy. There are three main aspects: allocation the relative size of the public and private sectors; distribution-the government's attempt to redress to some degree the inequalities in wealth and income; and stabilization-where the government aims to improve the overall economy through budgetery policy...The financial functions of the budget are analogous to accounting. Balance sheets need to be drawn up for the whole of government activity, in the same way as in the private sector. The financial functions of the budgets are: first, an evaluation of total government and public authority expenditures within the budget sector; and secondly, to act as the legislature's instrument of accountability and control over the government in its handling of financial matters. The first of these is a pure accounting function to set out estimates of receipts and expenditures. The second is an important part of the system of accountability.

Prinsip hukum keuangan negara yang mengandung spirit good governance, memiliki dampak efektif terhadap berbagai bidang pemerintahan. Dalam proses regulasi, beberapa aspek perlu dicermati ${ }^{8}$ : (1) Scope (what proportion of society is meant to be affected?); (2) The probability of a law affecting people; (3) The intensity of the impact; and (4) The frequency of impact. Keempat hal tersebut dapat terwujud dalam regulasi UU Nomor 17 Tahun 2003, yang secara signifikan akan berpengaruh terhadap penataan struktur dan sistem kelembagaan pemerintahan, manajemen personalia, proses evaluasi kinerja berdasarkan performance budgeting, akuntabilitas publik institusi-institusi pemerintahan, dan lain-lain.

Anggaran berbasis kinerja akan berpengaruh secara sistematis terhadap transformasi kelembagaan birokrasi pemerintahan ${ }^{9}$. Konsep

\footnotetext{
${ }^{7}$ Owen E. Hughes, Public Management and Administration -An Introduction, (New York: St. Martin's Press Inc, 1994), hlm. 192.

${ }^{8}$ Taylor, Charles Lewis, Why Government Grow-Measuring Public Sector Size, (New Delhi, London: Sage Publications, Beverly Hills, 1983), hlm. 163.

9 Rosul, Sjahrudin, Pengintegrasian Sistem Akuntabilitas Kinerja dan Anggaran Dalam Perspektif UU No. 17/2003 Tentang Keuangan negara-Problem dan Solusi Penganggaran di Indonesia, (Perum Percetakan Negara RI, 2003), hlm. 49.
} 
anggaran berbasis kinerja akan mengubah paradigma pemerintah menjadi lebih responsif terhadap masyarakat (pembayar pajak), dengan pendanaan program pada kinerja dan produksi.

Pengaruh prinsip good governanance dan gagasan democratic governance, juga tercermin secara implisit dalam prinsip hukum keuangan negara. Salah satunya, terlihat dari formula konsep anggaran sebagai alat akuntabilitas, manajemen, dan kebijakan ekonomi.

Prinsip akuntabilitas tercermin dari perubahan format anggaran, yang secara transparan diharuskan menyebutkan surplus/defisit dan policy yang dilakukan pemerintah menghadapi kondisi defisit anggaran. Hal tersebut mengubah konsep "anggaran berimbang" yang membawa pada "akuntabilitas semu", karena fungsi stabilisasi anggaran sangat bertumpu pada ekspansi hutang luar negeri yang "tidak bebas kepentingan”. Sebagai instrumen kebijakan ekonomi, anggaran berfungsi mewujudkan pertumbuhan, stabilitas perekonomian, dan pemerataan pendapatan dalam rangka mencapai tujuan bernegara.

Fungsi kontrol parlemen yang efektif sangat penting untuk mendukung akuntabilitas anggaran, dan menjaga konsistensi implementasi dari tujuan dan fungsi anggaran. Salah satu prinsip dari Reinventing Government menyebutkan adanya prinsip "funding outcomes, not input". Dalam hukum keuangan negara yang baru, hal itu tercermin dari akuntabilitas atas outcomes dari realisasi anggaran Negara.

Sisi demokratisasi penyelenggaraan pemerintah tercermin dari metode penyusunan rencana kerja dan pendanaan tersebut dengan menggunakan Rencana Kerja Kementerian Negara/Lembaga (Renja-KL) dan Rencana Kerja Pemerintah Daerah (RKPD) provinsi, kabupaten dan kota, sebagai input. Penyusunan Renja-KL sendiri berpedoman pada Rencana Strategis Kementerian Negara/Lembaga (Renstra-KL) dan mengacu pada prioritas pembangunan nasional, indikatif serta memuat kebijakan, program dan kegiatan pembangunan, baik yang dilaksanakan langsung oleh pemerintah, maupun yang ditempuh dengan mendorong partisipasi masyarakat.

Konsep anggaran berbasis kinerja merupakan instrument legal untuk melakukan proses transformasi sistem maupun kelembagaan organisasi pemerintahan. Mengingat terhadap setiap program/kegiatan di lingkungan organisasi-organisasi publik dilakukan analisis kinerja akuntabilitas, transparansi, partisipasi publik, dan ketaatan terhadap hukum akan selalu menjadi basis kinerja dari setiap aktivitas pemerintahan.

Pelembagaan prinsip good governance melalui konsep good budgeting merupakan esensi tujuan dari transformasi paradigma hukum keuangan negara. Pelayanan publik dengan mengacu pada standar pelayanan yang baik akan menjadi impact dari transformasi paradigma hukum keuangan negara. Eliminasi terhadap bias paradigma dalam pengelolaan 
keuangan negara, sebenarnya merupakan deklarasi kedaulatan negara di bidang keuangan negara yang selama ini diniscayakan.

\section{Desentralisasi Fiskal}

Konsep desentralisasi yang diberlakukan di Indonesia telah memberikan implikasi yang sangat mendasar terutama menyangkut kebijakan fiskal dan kebijakan administrasi negara. Rondinelli dan Cheema (1983), mendefinisikan desentralisasi sebagai transfer perencanaan, pengambilan keputusan dan atau kewenangan administrasi dari pemerintah pusat kepada organisasi pusat di daerah, unit administrasi lokal, organisasi semi otonomi dan parastatal (perusahaan), pemerintah daerah atau organisasi nonpemerintah. Perbedaan konsep desentralisasi ditentukan terutama berdasarkan tingkat kewenangan untuk perencanaan, memutuskan dan mengelola kewenangan yang ditransfer oleh pemerintah pusat dan besaran otonomi yang diterima untuk melaksanakan tugas-tugas tersebut.

Berbagai kajian dampak desentralisasi terhadap perekonomian dan public services delivery dapat dijelaskan dalam kerangka teori fiscal federalism. Teori ini dibagi dalam dua perspektif, yaitu teori tradisional atau teori generasi pertama (First Generation Theories) dan teori perspektif baru atau teori generasi kedua (Second Generation Theories). Dalam pandangan teori generasi pertama terdapat dua pendapat yang menekankan keuntungan alokatif desentralisasi.

Pertama adalah tentang penggunaan knowledge in society, yang menurut Hayek (1945) proses pengambilan keputusan yang terdesentralisasi akan dipermudah dengan penggunaan informasi yang efisien karena pemerintah daerah lebih dekat dengan masyarakatnya. Dalam konteks keuangan publik, pemerintah daerah mempunyai informasi yang lebih baik dibanding pemerintah pusat tentang kondisi daerah masing-masing, sehingga pemerintah daerah akan lebih baik dalam pengambilan keputusan penyediaan barang dan jasa publik dibanding penyediaan hal tersebut oleh pemerintah pusat. Keadaan ini disebut allocative efficiency.

Kedua, Tiebout (1956) memperkenalkan dimensi persaingan dalam pemerintah dan kompetisi antar daerah tentang alokasi pengeluaran publik memungkinkan masyarakat memilih berbagai barang dan jasa publik yang sesuai dengan selera dan keinginan mereka. Hal ini tidak terjadi jika pemerintah pusat sebagai penyedia barang dan jasa publik yang seragam.

Perhatian teori ini tidak menekankan pada kemampuan pemerintah daerah untuk self financing dalam membiayai pengeluaran. Pola ini sama dengan definisi devolusi pada desentralisasi administratif. Selanjutnya dalam pandangan teori generasi kedua yang dibangun oleh Musgrave (1959) dan Oates (1972) lebih menekankan pentingnya revenue dan expenditure assignment antar level pemerintahan. Teori ini menjelaskan bagaimana 
desentralisasi fiskal berpengaruh terhadap perilaku pemerintah daerah. Jika pemerintah daerah mempunyai kewenangan membuat peraturan tentang ekonomi lokal, maka campur tangan pemerintah pusat dalam perekonomian daerah dibatasi. Dengan demikian teori generasi kedua ini mendasarkan pada dua mekanisme dalam menyelaraskan antara kepentingan pemerintah daerah dengan kemakmuran ekonomi, interaksi horizontal antar pemerintah daerah, interaksi vertikal antar level pemerintahan. Mekanisme tersebut adalah :

a. dalam keadaan pasar barang dan jasa mobilitasnya tinggi, kompetisi antar pemerintah daerah merupakan alat insentif yang penting bagi penyediaan jasa publik. Persaingan antar pemerintah daerah dalam memberikan pelayanan kepada pasar akan mendorong pertumbuhan ekonomi di daerah. Sebaliknya jika peraturan pemerintah daerah dan penyediaan barang/jasa publik tidak bersahabat dengan pasar dan masyarakat, maka akan menimbulkan mobilitas faktor produksi ke daerah lain dan selanjutnya akan berdampak negatif terhadap petumbuhan ekonomi dan kesejahteraan masyarakat lokal.

b. keterkaitan yang erat antara penerimaan daerah dengan pengeluaran daerah juga menjadi insentif bagi pemerintah daerah dalam meningkatkan kemakmuran ekonomi daerah. Dengan demikian transfer dari pemerintah pusat yang besar akan menimbulkan disinsentif bagi pemerintah daerah dalam meningkatkan penerimaan daerah.

Dengan demikian perbedaan pokok kedua teori tersebut adalah terletak pada pandangan revenue transfer. Keterkaitan antara penerimaan dan pengeluaran pemerintah daerah serta pembatasan redistribusi pemerintah pusat kepada daerah akan menciptakan insentif bagi pemerintah daerah dalam melakukan reformasi orientasi pasar.

Hubungan keuangan antara pemerintah pusat dan daerah dapat diartikan sebagai suatu sistem yang mengatur bagaimana caranya sejumlah dana dibagi di antara berbagai tingkat pemerintah, serta bagaimana caranya mencari sumber-sumber pembiayaan daerah untuk menunjang kegiatankegiatan sektor publiknya. ${ }^{10}$ Perimbangan keuangan antara Pemerintah Pusat dan Daerah adalah suatu sistem pembiayaan pemerintahan dalam kerangka Negara kesatuan, yang mencakup pembagian keuangan antara Pemerintah Pusat dan Daerah serta pemerataan antar daerah secara proporsional, demokratis, adil, dan transparan dengan memperhatikan: potensi, kondisi, dan kebutuhan daerah, sejalan dengan kewajiban dan pembagian kewenangan serta tata cara penyelenggaraan kewenangan tersebut, termasuk pengelolaan dan pengawasan keuangan.

\footnotetext{
${ }^{10}$ Devas, Nick, et.al., Keuangan Pemerintah Daerah di Indonesia, (Jakarta: UI-Press,1989), hlm. 179.
} 
Instrumen yang digunakan dalam perimbangan keuangan antara Pusat dan Daerah adalah:

a. Dana perimbangan. Dana yang bersumber dari penerimaan APBN yang dialokasikan kepada daerah untuk membiayai kebutuhan Daerah dalam rangka pelaksanaan desentralisasi;

b. Dana Alokasi Umum (DAU). Dana yang berasal dari APBN, yang dialokasikan dengan tujuan pemerataan kemampuan keuangan antar daerah untuk membiayai kebutuhan pengeluarannya dalam rangka desentralisasi;

c. Dana Alokasi Khusus (DAK). Dana yang berasal dari APBN, yang dialokasikan kepada daerah untuk membantu membiayai kebutuhan tertentu;

d. Dana bagi hasil, pembagian hasil penerimaan dari (1) SDA dari antara lain: minyak bumi, gas alam, pertambangan umum, kehutanan, dan perikanan, dan (2) penerimaan perpajakan (tax sharing) dari antara lain: Pajak Perseorangan (PPh), Pajak Bumi dan Bangunan (PBB), dan Bea Perolehan Hak atas Tanah dan Bangunan (BPHTB); dan

e. Pengaturan relasi keuangan pemerintah pusat dan daerah.

Secara ideal tujuan dari kebijakan desentralisasi yang antara lain dilaksanakan melalui Dana Perimbangan Keuangan Pemerintah Pusat dan Daerah (PKPD) adalah:

a. dalam rangka pemberdayaan (empowerment) masyarakat dan pemerintah daerah agar tidak tertinggal di bidang pembangunan;

b. untuk mengintensifkan aktivitas dan kreativitas perekonomian masyarakat daerah yang berbasis pada potensi yang dimiliki masingmasing daerah. Pemda dan DPRD bertindak sebagai fasilitator dalam pembangunan ekonomi yang dilakukan oleh rakyatnya. Artinya dalam era otonomi daerah, rakyat harus berperan secara aktif dalam perencanaan dan pelaksanaan pembangunan daerahnya;

c. mendukung terwujudnya good governance oleh Pemerintah Daerah melalui perimbangan keuangan secara transparan; dan

d. untuk menyelenggarakan otonomi daerah secara demokratis, efektif, dan efisien, dibutuhkan SDM yang professional dan memiliki moralitas yang baik. Oleh sebab itu desentralisasi fiskal yang dilaksanakan melalui perimbangan keuangan akan meningkatkan kemampuan daerah dalam membangun dan pemberian pelayanan kepada masyarakat daerah. Bukan hanya sekedar pembagian dana, lalu terjadi "desentralisasi KN" dari Pusat ke Daerah.

Perimbangan keuangan antara pemerintah pusat dan daerah menurut pasal 1.1 UU Nomor 25 Tahun 1999 adalah suatu sistem pembiayaan pemerintahan dalam kerangka negara kesatuan, yang mencakup pembagian keuangan antara pemerintah pusat dan daerah serta pemerataan antar daerah 
secara proporsional, demokratis, adil, dan transparan dengan memperhatikan potensi, kondisi, dan kebutuhan daerah, sejalan dengan kewajiban dan pembagian kewenangan serta tata cara penyelenggaraan kewenangan tersebut, termasuk pengelolaan dan pengawasan keuangan.

Perimbangan keuangan antara pemerintah pusat dan daerah menurut Pasal 1 angka 1 UU Nomor 33 Tahun 2004 adalah suatu sistem keuangan pemerintahan dalam negara kesatuan, yang mencakup pembagian keuangan antara pemerintah pusat dan pemerintah daerah secara proporsional, demokratis, adil, transparan dengan memperhatikan potensi, kondisi, dan kebutuhan daerah, sejalan dengan kewajiban, pembagian kewenangan, dan tanggungjawab serta tata cara penyelenggaraan kewenangan tersebut.

Mengacu pada kedua definisi tersebut di atas, terlihat bahwa tidak terdapat perbedaan prinsip antar keduanya. Hal tersebut disebabkan pembagian keuangan antar pusat dan daerah merupakan konsekuensi dari otonomi daerah, yang secara tegas diakui dalam pasal 18, 18A, dan 18B UUD 1945. Hubungan keuangan antara pusat dan daerah ditujukan agar daerah dapat melaksanakan kewenangan otonominya sesuai dengan aspirasi dan kebutuhan masyarakat daerah. Di sisi lain, pemerintah pusat juga bertumpu pada masyarakat di daerah dalam memperoleh sumber-sumber keuangan melalui pajak, retribusi, dan sebagainya. Dengan demikian, alokasi anggaran oleh pusat kepada daerah sebenarnya merupakan wujud tanggungjawab pemerintah kepada rakyat di daerah yang dilaksanakan melalui berbagai bentuk pelayanan publik yang dilaksanakan oleh pemerintah daerah sebagai ujung tombak pelayanan kepada masyarakat. Pasal 2 ayat 1 UU Nomor 32 Tahun 2004 menegaskan bahwa perimbangan keuangan antara pemerintah pusat dan pemerintah daerah merupakan subsistem keuangan negara sebagai konsekuensi pembagian tugas antara pemerintah pusat dan pemerintah daerah.

Ada 4 (empat) kriteria yang perlu dipergunankan sebagai acuan untuk menjamin sistem hubungan antara pusat dan daerah ${ }^{11}$,yaitu:

a. sistem tersebut seharusnya memberikan kontribusi kekuasaan yang rasional di antara tingkat pemerintahan mengenai penggalian sumbersumber dana pemerintah dan kewenangannya, yaitu suatu pembagian yang sesuai dengan pola umum desentralisasi;

b. sistem tersebut seharusnya menyajikan suatu bagian yang memadai dari sumber-sumber dana masyarakat secara keseluruhan untuk membiayai pelaksanaan dan pembangunan yang diselenggarakan oleh pemerintah daerah;

c. sistem tersebut seharusnya sejauh mungkin mendistribusikan pengeluaran pemerintah secara adil di antara daerah-daerah atau sekurang-kurangnya

\footnotetext{
${ }^{11}$ Riawan Tjandra, Hukum Keuangan Negara, (Jakarta: Grasindo, 2013), hlm. 108.
} 
memberikan prioritas pada pemerataan pelayanan kebutuhan dasar tertentu; dan

d. pajak atau retribusi yang dikenakan oleh pemerintah daerah harus sejalan dengan distribusi yang adil atas beban keseluruhan dari pengeluaran pemerintah dalam masyarakat.

Salah satu pilar pokok otonomi daerah adalah kewenangan daerah untuk mengelola secara mandiri keuangan daerahnya. Indonesia sebagai suatu unitary state menganut kombinasi antara unsur pengakuan kewenangan bagi daerah untuk mengelola secara mandiri keuangannya dipadukan dengan unsur kewenangan pemerintah pusat untuk melakukan transfer fiskal dan melakukan pengawasan terhadap kebijakan fiskal daerah. Pemerintah pusat perlu menyadari bahwa penekanan yang berlebihan terhadap unsur yang kedua, akan membawa ke arah resentralisasi diam-diam di bidang fiskal yang merupakan antithesis terhadap semangat desentralisasi.

\section{Pilihan Politik Hukum Penguatan Desentralisasi Fiskal dalam Pengelolaan Keuangan Daerah}

Salah satu prasyarat konstitusi negara modern (modern constitutional state) adalah negara hukum (the rule of law atau rechtstaats) ${ }^{12}$ yang ditandai pembatasan kekuasaan dalam penyelenggaraan kekuasaan negara. Paul Scholten mengatakan negara hukum adalah suatu konsep hukum yang bertujuan membatasi kekuasaan. ${ }^{13}$ Kekuasaan dibidang eksekutif, legislatif, dan yudikatif. Pembatasan itu dilakukan dengan hukum yang kemudian menjadi ide dasar paham konstitusionalisme modern. ${ }^{14}$

Miriam Budiardjo ${ }^{15}$, menyebutkan bahwa kekuasaan negara dibagi secara vertikal dan horizontal. Secara vertikal yaitu membagi kekuasaan berdasarkan tingkatan atau hubungan antar tingkatan pemerintahan dan secara horizontal membagi kekuasaan menurut fungsinya yaitu membedakan antara fungsi-fungsi pemerintahan yang bersifat legislatif, eksekutif, dan yudikatif. ${ }^{16}$ Pola-pola pemilahan pembagian kekuasaan dengan pendekatan trias politika disertai dengan prinsip check and balances yang menghendaki

12 Disini tidak dibedakan antara konsep "rule of law" dan konsep "rechtstaat”. Untuk menelusuri perbedaan kedua konsep itu dapat dibaca, misalnya dalam Philipus M. Hadjon, Perlindungan Hukum Bagi Rakyat di Indonesia, (Surabaya: Bina Ilmu, 1987), Lihat juga, Ridwan HR, Hukum Administrasi Negara, (Yogyakarta: UII Press, 2003), hlm. 1-16, Lihat juga, Marjanne Termorshuizen Artz, The Concept of Rule of Law, Jurnal Jentera Edisi 3, Tahun II, November, Pusat Studi Hukum dan Kebijakan, Jakarta.

${ }^{13}$ Paul Scholten, Verzamelde Gerchriften (Zwolle: W.E.J Tjeenk Willink, 1949), hlm 322.

${ }^{14}$ Jimly Asshiddiqie. Pengantar Hukum Tata Negara, Jilid II (Jakarta: Sekretariat Jenderal dan Kepaniteraan RI, 2006), hlm. 11.

15 Miriam Budiardjo, Dasar-dasar Ilmu Politik, (Jakarta: PT. Gramedia Pustaka Utama, 1989), hlm. 138.

${ }^{16}$ Ibid. 
kesederajatan antar lembaga, keterpisahan karena wewenang, ataupun dengan model hirarkis struktural yang bersifat vertikal sejatinya tidaklah dapat dilepaskan dari argumen pilihan politik hukum yang diambil saat penentuan pilihan tersebut. Demikian pula politik hukum dalam tata kelola fiskal daerah.

Guna mendapatkan pemahaman yang lebih akademis terkait politik hukum penguatan desentralisasi fiskal keuangan daerah, berikut definisidefinisi politik hukum menurut beberapa ahli hukum dan kenegaraan :

a. Ali Abdurahman, ${ }^{17}$ menyebutkan bahwa Politik Hukum merupakan kebijaksanaan menguasai penciptaan, pembaharuan dan pengembangan hukum dengan melihat pada:

1) kebijaksanaan peraturan perundang-undangan;

2) kebijaksanaan hukum yurisprudensi; dan

3) kebijaksanaan terhadap peraturan tidak tertulis lainnya.

b. Abdul Bari Azed, mengartikan Politik Hukum ${ }^{18}$ merupakan kebijakan dasar penyelenggaraan negara dalam bidang hukum yang akan, sedang, dan telah berlaku, yang bersumber dari nilai-nilai yang berlaku di masyarakat untuk mencapai tujuan negara yang dicita-citakan, ruang lingkup kajian dari politik hukum, ${ }^{19}$ adalah:

1) proses penggalian nilai-nilai dan aspirasi yang berkembang dalam masyarakat;

2) proses perdebatan dan perumusan nilai-nilai dan aspirasi tersebut kedalam bentuk sebuah rancangan undang-undang;

3) penyelenggara negara yang berwenang merumuskan dan menetapkan politik hukum;

4) peraturan perundang-undangan yang memuat politik hukum;

5) faktor-faktor yang mempengaruhi dan menentukan suatu politik, baik yang akan, sedang, dan telah ditetapkan; dan

6) pelaksanaan peraturan perundang-undangan yang merupakan implementasi dari politik hukum suatu negara.

c. Notohamidjojo, mengatakan menentukan tujuan-tujuan sosial secara tepat tidak mungkin tanpa visi terhadap manusia dan masyarakat. ${ }^{20}$ Pada akhirnya, dengan menggunakan bentuk politik (disini demokrasi), maka tindakan-tindakan politik harus dirumuskan dalam bentuk undang-

17 Dosen Mata Kuliah: Politik Hukum, Program Doktor Universitas Padjadjaran Bandung 2014.

18 Abdul Bari Azed, Politik Hukum, Materi kuliah Program Pascasarjana Magister Hukum Fakultas Hukum Universitas Indonesia, 2008, hlm. 16.

${ }^{19}$ Ibid, hlm 21.

${ }^{20}$ O. Notohamidjojo, Makna Negara Hukum (Djakarta: Badan Penerbit Kristen, 1970), hlm. 98. 
undang. ${ }^{21}$ Politik hukum itu kebijaksanaan pemerintah negara yang menentukan tujuan dan isi undang-undang. Politik hukum itu tergantung daripada perjuangan politik yang hasilnya dikristalisasikan dalam undang-undang itu. ${ }^{22}$

d. Padmo Wahyono. Politik hukum adalah kebijakan dasar yang menentukan arah, bentuk maupun isi dari hukum yang akan dibentuk, ${ }^{23}$ atau kebijakan penyelenggara negara tentang apa yang dijadikan kriteria untuk menghukum sesuatu. Kebijakan tersebut dapat berkaitan dengan pembentukan hukum, penerapan hukum, dan penegakannya sendiri. ${ }^{24}$

e. Soedarto. Politik hukum adalah kebijakan dari negara melalui badanbadan negara yang berwenang untuk menetapkan peraturan-peraturan yang dikehendaki, diperkirakan akan digunakan untuk mengekspresikan apa yang terkandung dalam masyarakat dan untuk mencapai apa yang dicita-citakan. ${ }^{25}$

f. Satjipto Rahardjo. Mengutip pengertian politik menurut Parson, Satjipto Rahadjo mendefinisikan politik hukum sebagai aktivitas memilih dan cara yang hendak dipakai untuk mencapai suatu tujuan sosial dan hukum tertentu dalam masyarakat. ${ }^{26}$ Menurut Satjipto Rahardjo terdapat beberapa pertanyaan mendasar yang muncul dalam studi politik hukum yaitu :

1) tujuan apa yang hendak dicapai dengan sistem hukum yang ada;

2) cara-cara apa dan yang mana, yang dirasa paling baik untuk bisa dipakai mencapai tujuan tersebut;

3) kapan waktunya hukum itu perlu diubah dan melalui cara-cara bagaimana perubahan itu sebaiknya dilakukan; dan

4) dapatkah dirumuskan suatu pola yang baku dan mapan, yang bisa membantu kita memutuskan proses peralihan tujuan serta cara-cara untuk mencapai tujuan tersebut secara baik. ${ }^{27}$

g. C.F.G. Sunaryati Hartono. Ia melihat politik hukum sebagai alat (tool) atau sarana dan langkah yang dapat digunakan oleh pemerintah untuk

\footnotetext{
${ }^{21}$ Ibid.

${ }^{22}$ Ibid.

${ }^{23}$ Padmo Wahyono, Indonesia Negara Berdasarkan atas Hukum, Cet. II. (Jakarta: Ghalia Indonesia, 1986), hlm 160.

24 Padmo Wahyono, Menyelisik Proses Terbentuknya Perundang-undangan, (Forum Keadilan, No. 29/ April, 1991), hlm. 65.

${ }^{25}$ Soedarto, Hukum Pidana dan Perkembangan Masyarakat Kajian terhadap Hukum Pidana, (Bandung; Sinar Baru, 1983), hlm 20.

${ }^{26}$ Satjipto Rahardjo, Ilmu Hukum, Cet. III. (Bandung; Citra Aditya Bakti, 1991), hlm 352.

${ }^{27}$ Ibid, hlm. 352-353.
} 
menciptakan sistem hukum nasional yang dikehendaki dan dengan sistem hukum nasional itu akan diwujudkan cita-cita bangsa Indonesia. ${ }^{28}$ dan

h. Imam Syaukani dan A. Ahsin Thohari. Politik hukum adalah kebijakan dasar penyelenggara negara dalam bidang hukum yang akan, sedang, dan telah berlaku, yang bersumber dari nilai-nilai yang berlaku di masyarakat untuk mencapai tujuan negara yang dicita-citakan. ${ }^{29}$

Berdasarkan rumusan tersebut dapat disimpulkan politik hukum merupakan konsep dan asas yang menjadi garis besar dan dasar rencana pelaksana negara dalam hal pembentukan dan pelaksanaan kebijakan legislasi yang bersumber pada nilai-nilai yang berkembang di masyarakat untuk mencapai tujuan bernegara sesuai dengan Pancasila dan UndangUndang Dasar 1945, demikian halnya dengan politik hukum penguatan desentralisasi fiskal keuangan daerah.

Otonomi daerah yang dihasilkan melalui devolusi kekuasaan Negara hanya akan membawa pengaruh positif yang melembaga di bidang pelayanan publik, jika diimbangi dengan penguatan sistem fiskal daerah. Perubahan dari UU No. 25/1999 menjadi UU No. 33/2004 tentang Perimbangan Keuangan antara Pusat dan Pemerintah Daerah dilaksanakan dalam rangka penguatan/perbaikan sistem fiskal daerah.

Pengelolaan keuangan untuk kepentingan penyelenggaraan urusan pemerintah daerah yang dilakukan daerah sendiri masih diyakini oleh masyarakat mampu menjamin tercapainya derajat akuntabilitas yang lebih tinggi, daripada jika semua aspek keuangan untuk kepentingan daerah ditangani oleh Pusat secara sentralistik.

Perkembangan pengaturan di bidang keuangan negara ternyata memperlihatkan kecenderungan ke arah resentralisasi sistem kekuasaan, sekurang-kurangnya di bidang fiskal. Ditinjau dari sudut pembiayaan pemerintahan, karena instrumen fiskal merupakan instrumen vital dalam penyelenggaraan kekuasaan, resentralisasi di bidang fiskal dapat mereduksi makna otonomi bagi daerah.

Melihat kondisi resentralisasi di bidang fiskal ini, kiranya diperlukan suatu terobosan dalam politik hukum keuangan negara khususnya dalam rangka penguatan desentralisasi fiskal dalam pengelolaan keuangan daerah yang lebih baik melalui penyempurnaan regulasi keuangan daerah yang mengakomodir prinsip-prinsip sebagai berikut ${ }^{30}$ :

a. Otonomi. Ini merupakan prinsip yang mendasari desentralisasi fiskal, apakah suatu Negara itu berbentuk federal maupun Negara kesatuan.

\footnotetext{
${ }^{28}$ C.F.G. Sunaryati Hartono, Politik Hukum Menuju Satu Sistem Hukum Nasional. (Bandung; Alumni, 1991), hlm. 1.

${ }^{29}$ Imam Syaukani dan A. Ahsin Thohari, Op cit, hlm. 32

${ }^{30}$ Machfud Sidik, dkk, Dana Alokasi Umum - Konsep, Hambatan, dan Prospek di Era Otonomi Daerah, (Jakarta: Penerbit Buku Kompas, 2002), hlm. 28-30.
} 
Intinya adalah bahwa pemerintah daerah harus memiliki independensi dan fleksibilitas dalam menentukan prioritas-prioritas mereka. Tidak boleh ada pembatasan yang sedemikian ketat sehingga sebagian besar keputusan di daerah harus mengikuti dan mengacu kepada ketentuan pusat. Pajak-pajak di mana daerah bisa ikut memungut di atas tingkat yang ditetapkan pusat (piggyback), bagi hasil (revenue-sharing) berlandaskan formula ataupun transfer yang bersifat umum (block grant) adalah sumber-sumber penerimaan daerah yang konsisten dengan tujuan tersebut.

b. Penerimaan yang memadai (revenue adequacy). Pemerintah daerah semestinya memiliki pendapatan (termasuk transfer) yang cukup untuk menjalankan segala kewajiban atau fungsi yang diembannya.

c. Keadilan (equity). Besarnya dana transfer dari pusat ke daerah ini syogyanya berhubungan positif dengan kebutuhan fiskal daerah, dan sebaliknya berkebalikan dengan besarnya kapasitas fiskal daerah yang bersangkutan.

d. Transparan dan stabil. Formula transfer mesti diumumkan sehingga dapat diakses masyarakat. Hal yang lebih penting lagi adalah bahwa setiap daerah dapat memperkirakan berapa penerimaan totalnya (termasuk transfer), sehingga memudahkan penyusunan anggaran. Formula tersebut juga seyogyanya dipakai untuk jangka menengah (misalnya 3-5 tahun). Agar perencanaan jangka menengah dan panjang dapat dilakukan oleh daerah.

e. Sederhana ( simplicy). Alokasi dana kepada pemerintah daerah semestinya didasarkan pada faktor-faktor objektif dimana unit-unit individual tidak memiliki kontrol atau tidak dapat mempengaruhinya. Disamping itu juga formula yang dipakai seyogyanya relatif mudah untuk dipahami.

f. Insentif. Desain dari transfer ini harus sedemikian sehingga memberikan semacam insentif bagi daerah dengan manajemen fiskal yang baik. Dan sebaliknya menangkal praktek-praktek yang tidak efisien. Dengan demikian, tidak perlu ada transfer khusus/spesifik untuk membiayai defisit anggaran pemerintah daerah, atau ada semacam kontrol terhadap belanja daerah.

Hal lain yang perlu menjadi perhatian adalah terkait dengan pola pengelolaan keuangan Pemda yang saat ini lebih banyak mempergunakan pendekatan pelayanan bersifat demand-driven (bottom up) dibandingkan supply-driven (top down). Belajar dari pengalaman desentralisasi fiskal Kolumbia, penerapan pola pengelolaan keuangan lokal semacam itu mampu berpengaruh terhadap peningkatan kualitas pemuasan referensi kebutuhan sesuai dengan yang diinginkan oleh rakyat daerah, daripada yang dianggap dibutuhkan oleh daerah menurut penilaian orang-orang pusat. Dalam kondisi 
semacam itu, tumbuhnya kehidupan lokal baru semakin ditandai oleh meningkatnya partisipasi rakyat ${ }^{31}$.

Dalam tata kelola keuangan daerah saat ini, pengaturan sistem fiskal daerah antara lain melalui dana perimbangan, yakni dana yang bersumber dari pendapatan APBN yang dialokasikan kepada daerah untuk mendanai kebutuhan daerah dalam rangka pelaksanaan desentralisasi. Dana perimbangan tersebut terdiri dari 3 (tiga) komponen meliputi: Dana Bagi Hasil (DBH), Dana Alokasi Umum (DAU), dan Dana Alokasi Khusus (DAK).

Komitmen penguatan sistem fiskal daerah yang terlihat dalam proporsi DAU yang dalam alokasinya ditentukan berdasarkan sistem imbangan sebesar $10 \%$ untuk provinsi dan $90 \%$ untuk kabupaten/kota. Jumlah keseluruhan DAU secara nasional ditetapkan tidak boleh kurang dari 26\% daripada pendapatan dalam negeri neto. Hal tersebut berarti desentralisasi fiskal yang terfokus pada kabupaten/kota mengharuskan dilakukannya peningkatan transparansi dan akuntabilitas publik oleh kabupaten/kota dalam menyelenggarakan urusan pemerintahan yang didevolusikan pusat kepada daerah tersebut, hal ini diperlukan apabila kita belajar dari kegagalan implementasi UU Nomor 22 Tahun 1999 yang tidak diperkuat dengan sistem dan transparansi dan akuntabilitas keuangan daerah.

Pemerintah daerah perlu melakukan beberapa hal dalam kerangka peningkatan akuntabilitas tersebut, antara lain:

Pertama, pola penyajian informasi keuangan daerah yang sangat teknis dalam bahasa akuntansi keuangan, seringkali belum diimbangi oleh kapasitas/kompetensi masyarakat untuk melakukan penilaian terhadap ketepatan data dan fakta yang disajikan dalam informasi keuangan daerah tersebut. Hal ini dapat dilakukan dengan cara Pemda menyusun panduan analisis keuangan yang mudah dipahami oleh masyarakat awam sekalipun, sehingga bisa merespon informasi keuangan daerah yang disampaikan oleh Pemda.

Kedua, penyampaian informasi keuangan daerah semacam itu lebih memperlihatkan sistem komunikasi searah, sebagai akibat belum adanya kapasitas pengawasan publik yang memadai oleh masyarakat, guna membangun sistem komunikasi dua arah dalam wujud koreksi/evaluasi publik terhadap kinerja anggaran daerah. Hal ini dapat dilakukan dengan cara Pemda mempermudah akses masyarakat yang telah "melek fiskal" tersebut guna memberikan masukan, usulan sampai pada koreksi terhadap informasi keuangan daerah yang disajikan oleh Pemda, misalnya dengan

31 Bird, M.Richard, dk, Desentralisasi Fiskal Di Negara-Negara Berkembang (Fiscal Decentralization in Develoving Countries), (Jakarta: Gramedia Pustaka Utama, 2000), hlm. 30. 
mengeluarkan Perda mengenai transparansi, partisipasi, dan akuntabilitas publik.

Belajar dari kegagalan Pakistan dalam sistem desentralisasi fiskalnya karena ketiadaan suara rakyat dalam pengendalian akuntabilitas keuangan lokal. Sebaliknya, India sebelum masa penjajahan Inggris justru berhasil dalam mengelola sistem desentralisasi fiskalnya, karena ada mekanisme partisipasi dan akuntabilitas keuangan lokal kepada rakyat. Indonesia bisa belajar dari kedua pengalaman tersebut. Desentralisasi (tanpa) fiskal maupun fiskal (tanpa) desentralisasi sama-sama mencederai demokrasi. Absennya transparansi dan akuntabilitas fiskal dalam sistem devolusi kekuasaan Negara, cepat atau lambat hanya memastikan hadirnya salah satu atau kedua hal tersebut.

Pelembagaan prinsip good governance melalui penerapan best practice dalam budgeting, merupakan esensi tujuan dari transformasi paradigma regulasi fiskal. Pelayanan publik dengan mengacu pada standar pelayanan yang baik akan menjadi impact dari transformasi paradigma fiskal. Eliminasi terhadap bias paradigma dalam pengelolaan keuangan negara, sebenarnya merupakan deklarasi kedaulatan Negara di bidang fiskal, yang selama ini diniscayakan.

\section{Penutup}

Uraian-uraian dimuka menghasilkan simpulan sebagai berikut :

a. politik hukum yang merupakan konsep dan asas yang menjadi garis besar dan dasar rencana pelaksana negara dalam hal pembentukan dan pelaksanaan kebijakan legislasi yang bersumber pada nilai-nilai yang berkembang di masyarakat untuk mencapai tujuan bernegara sesuai dengan Pancasila dan Undang-Undang Dasar 1945 yang juga tercermin dalam pengelolaan keuangan negara. Pembaruan sistem pengelolaan keuangan negara dengan ditetapkannya beberapa undang-undang dalam pengelolaan keuangan negara, antara lain dengan mengatur prinsipprinsip terbaik (best practice) pengelolaan keuangan negara, sistem penganggaran dan struktur APBN, rentang kendali (span of control) administrasi keuangan, mekanisme pengawasan, dan pertanggungjawaban pengelolaan keuangan negara demikian halnya pada pengelolaan keuangan daerah. Namun demikian, perkembangan pengaturan di bidang keuangan negara ternyata memperlihatkan kecenderungan ke arah resentralisasi sistem kekuasaan, sekurangkurangnya di bidang fiskal, sehingga diperlukan politik hukum berupa penguatan kembali desentralisasi fiskal pengelolaan keuangan daerah dalam rangka mencapai kesejahteraan seluruh rakyat Indonesia;

b. salah satu pilar pokok otonomi daerah adalah kewenangan daerah untuk mengelola secara mandiri keuangan daerahnya. Indonesia sebagai suatu 
unitary state menganut kombinasi antara unsur pengakuan kewenangan bagi daerah untuk mengelola secara mandiri keuangannya dipadukan dengan unsur kewenangan pemerintah pusat untuk melakukan transfer fiskal dan melakukan pengawasan terhadap kebijakan fiskal daerah;

c. Terobosan dalam politik hukum keuangan negara khususnya dalam rangka penguatan desentralisasi fiskal pengelolaan keuangan daerah adalah perlunya penyempurnaan regulasi yang mengakomodir prinsipprinsip pengelolaan keuangan daerah yang baik, antara lain: (1) Otonomi; (2) Penerimaan yang memadai (revenue adequacy); (3) Keadilan (equity); (4) Transparan dan stabil; (5) Sederhana (simplicy); dan (6) Insentif;

d. penguatan desentralisasi fiskal yang terfokus pada kabupaten/kota mengharuskan dilakukannya peningkatan transaparansi dan akuntabilitas publik oleh kabupaten/kota dalam menyelenggarakan urusan pemerintahan yang didevolusikan pusat kepada daerah tersebut, hal ini diperlukan apabila kita belajar dari kegagalan implementasi UU Nomor 22 Tahun 1999 yang tidak diperkuat dengan sistem dan transparansi dan akuntabilitas keuangan daerah;

e. pemerintah daerah perlu melakukan beberapa hal dalam kerangka peningkatan akuntabilitas tersebut, antara lain: pertama, Pemda menyusun panduan analisis keuangan yang mudah dipahami oleh masyarakat awam sekalipun, sehingga bisa merespons informasi keuangan daerah yang disampaikan oleh Pemda. Kedua, Pemda mempermudah akses masyarakat yang telah "melek fiskal" tersebut guna memberikan masukan, usulan sampai pada koreksi terhadap informasi keuangan daerah yang disajikan oleh Pemda, misalnya dengan mengeluarkan Perda mengenai transparansi, partisipasi, dan akuntabilitas publik.

\section{Daftar Pustaka}

\section{A. Buku}

Asshiddiqie, Jimly, 2006. Pengantar Hukum Tata Negara, Jilid II, Sekretariat Jenderal dan Kepaniteraan RI.

Atmadja, Arifin P. Soeria, 2009. Keuangan Publik dalam Perspektif Hukum, Teori, Praktek dan Kritik, Jakarta : Rajawali Pers.

Bird, Richard M., dkk., 2000. Desentralisasi Fiskal Di Negara-Negara Berkembang (Fiscal Decentralization in Develoving Countries), Jakarta: Gramedia Pustaka Utama.

Budiardjo, Miriam, 1989. Dasar-dasar Ilmu Politik, Jakarta: PT Gramedia Pustaka Utama. 
Devas, Nick, et,al., 1998. Keuangan Pemerintah Daerah di Indonesia, Jakarta: UI-Press.

Handyaningrat, Soewarno, 1982. Administrasi Pemerintahan Dalam Pembangunan Nasional, Jakarta: Haji Masagung.

Hughes, Owen E., 1994. Public Management and Administration-An Introduction, New York: St. Martin's Press Inc.

MD, Moh. Mahfud, 2010. Perdebatan Hukum Tata Negara Pascaamandemen Konstitusi, Jakarta: PT Raja Grafindo Persada.

Notohamidjojo, O., 1970. Makna Negara Hukum, Djakarta: Badan Penerbit Kristen.

Rahardjo, Satjipto, 1991. Ilmu Hukum, Cet, III, Bandung: Citra Aditya Bakti.

Rosul, Sjahrudin, 2003. Pengintegrasian Sistem Akuntabilitas Kinerja dan Anggaran Dalam Perspektif UU No, 17/2003 Tentang Keuangan negara-Problem dan Solusi Penganggaran di Indonesia, Perum Percetakan Negara RI.

Sidik, Machfud, dkk., 2002. Dana Alokasi Umum - Konsep, Hambatan, dan Prospek di Era Otonomi Daerah, Jakarta: Penerbit Buku Kompas.

Soedarto, 1983. Hukum Pidana dan Perkembangan Masyarakat Kajian terhadap Hukum Pidana, Bandung: Sinar Baru.

Taylor, Charles Lewis, Why Government Grow-Measuring Public Sector Size, Beverly Hills, London, New Delhi: Sage Publications.

Wahyono, Padmo, 1986. Indonesia Negara Berdasarkan atas Hukum, Cet. II, Jakarta: Ghalia Indonesia.

W., Riawan Tjandra, 2013. Hukum Keuangan negara, Jakarta: Grasindo.

\section{B. Peraturan Perundang-undangan}

Republik Indonesia, Undang-Undang Nomor 1 Tahun 2004 tentang Perbendaharaan Negara (Lembaran Negara Republik Indonesia Tahun 2004 Nomor 5, Tambahan Lembaran Negara Republik Indonesia Nomor 4355).

Republik Indonesia, Undang-Undang Nomor 17 Tahun 2003 tentang Keuangan negara (Lembaran Negara Republik Indonesia Tahun 2003 Nomor 47, Tambahan Lembaran Negara Republik Indonesia Nomor 4286).

Republik Indonesia, Undang-Undang Nomor 19 Tahun 2003 tentang Badan Usaha Milik Negara (Lembaran Negara Republik Indonesia Tahun 2003 Nomor 70, Tambahan Lembaran Negara Republik Indonesia Nomor 4286)

\section{Lain-lain}

Abdul Bari Azed, Politik Hukum, Materi kuliah Program Pascasarjana Magister Hukum Fakultas Hukum Universitas Indonesia. 
Padmo Wahyono, Menyelisik Proses Terbentuknya Perundang-undangan, Forum Keadilan, No, 29/ April, 1991. 